\title{
Impacts of Global Multilateral Trade Liberalization on Sustainability Indicators
}

\author{
J. Zhang \\ University of Hawaii \\ A. Dobranskyte \\ Institute for Environment and Sustainability \\ M. Berrittella \\ University of Palermo
}

\begin{abstract}
A computable general equilibrium model was used to analyze trade liberalization impacts on sustainability. On the basis of multilateral trade negotiations in Doha Round, partial trade liberalization (PTL) and deep trade liberalization (DTL) scenarios were designed to assess their impacts on economic, social and environmental dimensions of sustainability using selected indicators. In a short time period DTL scenario showed high sustainability performance for developed and developing regions. In a longer time period gradual trade liberalization (PTL) appeared to be more beneficial in terms of sustainability performance for developing and least developed regions. Under both PTL and DTL scenarios, the least developed countries would be worse off than more developed regions, suggesting that special treatments and time frame may need to be considered in future negotiation talks.
\end{abstract}

- JEL classification: F13, Q01, C68

- Keywords: Trade liberalization, Sustainable development, Computable general

\footnotetext{
*Corresponding address: Current affiliation: Department of Economics, University of Hawaii at Manoa, University of Hawaii Economic Research Organization, 2424 Maile Way, Saunders Hall 540, Honolulu, HI 96822, U.S.A., Email: zhjian@ hawaii.edu, Phone: 808-956-2325, Fax: 808-956-4347 
equilibrium model

\section{Introduction}

Since the past two decades trade liberalization and its role in achieving sustainability has been a subject of several major international trading negotiations namely Uruguay Round and Doha Round, which implies close links between the underlying issues of global importance such as trade and sustainable development.

The term "sustainable development" or "sustainability" was defined by the World Commission on Environment and Development (WCED) in the 1987 Brundland report as "development that meets the needs of the present without compromising the ability of future generations to meet their own needs" (WCED, 1987). The concept relates to the continuity of economic, social, institutional and environmental aspects of human society, as well as the non-human environment. The concern is raised as a result of accelerating global population growth, depletion of non-renewable resources, over exploitation of renewable resources, the generation of waste and pollution, and the need to improve living standards in the developing world. Several other definitions of sustainability are found in additional papers (Pezzey, 1989, 1992; Solow, 1992; Heal, 1998; Asheim, 2003). These authors mainly focus on the economic dimension of sustainability by relating sustainability to "economic capital" and by referring to it as "wellbeing that does not decline over time", or "an economic development that lasts". Various interpretations of sustainability were discussed also in Arrow et al. (2003, 2004), Asheim (1994) and Dasgupta and Heal (1979). Arrow et al. (2004) ask a question of whether consumption is or is not excessive. These authors examine a criteria of sustainability, which emphasizes the ability of economy to maintain living standards, and identified factors in the economic and ecological domains that determine whether or not it is in fact so.

The global aim is to highlight the positive links between trade liberalization and sustainability, especially in combating poverty and finding the balance of ecosystems. Thus, it is necessary to find a better method to calibrate trade agreements so that they bring economic, environmental and social benefits. Trade liberalization policies may be an effective tool in reducing the poverty gap between developed and developing regions of the world by expanding market access opportunities (Suppan, 2005). Sustainability aims at reversing the apparent trend of marginalization of many countries from the benefits of globalizing world economy 
(Moosa, 2002). Thus, discussions on trade liberalization, e.g. Doha Round negotiations in Qatar (WTO, 2001), are of significant importance. The Doha Round negotiations defined the obligations for developing country member governments with respect to issues such as agriculture, subsidies, textiles and clothing, technical barriers to trade, trade-related investment measures and rules of origin. Developed countries accordingly committed to far-reaching structural adjustments in their economies by reducing a range of protection and support measures applied to inefficient industries and sectors. Francois et al. (2005) demonstrated that developing countries could gain substantially from the Doha Round. These authors also argued that the South-South trade liberalization is also very critical for greater development. However, the Doha Round has been suspended recently due to significant disagreements between developed and developing regions. As a result, the world trading system maybe divided into bilateral and regional deals, causing the multilateral system to wither. The theoretical aspect of trade liberalization originates from traditional trade theory. It includes some well known theories such as comparative advantage, the Heckscher-Ohlin theorem, the Stolper-Samuelson theorem and gain from trade theorem. In the past two decades, various trade liberalization studies were conducted worldwide at regional or national level. Most of the empirical studies regarding trade liberalization find that trade reform can improve productivity growth, technology development, lower mark-ups and reallocating resources towards more efficient sectors. Although in some cases the evidences fail to confirm these results. Traditional trade theory supports the allocation efficiency argument in the perfect competition framework. Since 1980s new trade theory relaxed the perfect competition assumption to imperfect competition content. It argues that trade liberalization can also improve efficiency by introducing competition from foreign firms. There exist rich empirical studies on trade liberalization impact assessment (Lofgren, et al., 1999; Thurlow et al., 2002; Hertel, 2003, 2004; Harrison et al., 2002; Zhai et al., 2004). Most of these papers focus on regional or national trade liberalization impacts on growth, productivity, equality, income distribution or poverty, food security, etc., especially on the effects which are crucial for the developing countries. Instead of focusing on one national area or one region, our paper studies the trade liberalization impacts at global level. On the one hand, this general overview is said to be a disadvantage for this paper since we do not focus on impacts on single country level. On the other hand, it is quite a unique approach to provide a general view of global multilateral trade impacts given the limited data sources that we have at global level. In this paper, 
we address the question of how multilateral trade liberalization affects sustainability at the global level in three dimensions: economically, socially and environmentally. We study the effects of trade liberalization policies focusing on the three global areas such as developed, developing and least developed regions. The grouping of regions is explained further on in the text. Our experimental methodology is quite novel and the design of the experiment is unique. The objective aims to provide qualitative results regarding multilateral trade liberalization, which may be helpful for future trade negotiations talks. In particular, we present a computable general equilibrium (CGE) model, called GTAP-ST, designed to account for selected sustainability indicators. The GTAP-ST model aims to improve our understanding of the interactions between trade and sustainability. Furthermore, this paper compares the impacts of two different hypothetical Doha Round trade liberalization policies in 2010 and its development up to 2030: partial and deep trade liberalization. We found that in the short term period developed and developing regions are the gainers in terms of sustainability performance in deep trade liberalization (DTL) scenario, while for the least developed regions partial trade liberalization (PTL) is a more acceptable policy scenario. However, liberalizing trade does not automatically result in environmental and social gains. Our sustainability indicators reveal that while both developed and developing countries gain economically, the impacts of partial trade liberalization on social development are negative and environmental performance is dependent on economic growth. This paper is organized as follows. Section 2 focuses on the selection and calculation of sustainability indicators and sustainability scores. Section 3 presents GTAP-ST model and data sources. Section 4 presents the design of model experiments by defining and explaining applied trade liberalization policy scenarios. Section 5 includes the discussion of the results obtained from the simulations. Section 6 concludes.

\section{Sustainability Indicators}

Sustainability is a multidisciplinary topic covering many different aspects. In order to obtain some level of its quantification, it is needed to choose the represen- tative components. For this reason in this study we have developed the GTAP-ST model, which includes a set of selected representative sustainability indicators: GDP per capita, investment as percentage (\%) of GDP, public expenditure per capita, $\mathrm{CO}_{2}$ emissions and water resources use per capita. In principle, GTAP model is strongly 
based on economic variables as it is a model of global economy, however, there are also few social and environmental variables present in the model. Selecting more sustainability indicators was limited to our availability of data within the GTAP model base. However, we strongly believe that these indicators are adequate representatives for analyzing the impact of trade liberalization on sustainability. Provisionally, our selected indicators take into account the main variables of three systems: economic (GDP per capita, and investment as percentage of GDP), social (public expenditure per capita, which aggregates information about expenditure on public administration, defense, health and education) and environ- mental $\left(\mathrm{CO}_{2}\right.$ emissions and water resources use per capita). It must be noted that GTAP-ST model includes only indicators, sustainability scores are not calculated within GTAP-ST model, but derived from the model results and calculated outside of the model.

In order to transform the selected sustainability indicators into comparable scale, they were first normalized by applying standardization method following Nardo et al. (2005). Normalization included converting variables to a common range with a mean of zero and standard deviation of one. This was performed by subtracting the average value and dividing by the standard deviation, similarly as it was performed in the "2005 Environmental Sustainability Index". Subsequently, sustainability scores were calculated using Equally Weighted Average (EWA) method, where the indicators were equally averaged to obtain the values of the three components of sustainability. Then the resulting values were equally averaged to obtain the sustainability score. The EWA is the most commonly used aggregation technique and it has been applied to numerous sustainability indices such as Human Development Index (UNDP, 2001) and Environmental Sustainability Index (Yale Center of Environmental Law and Policy and Center for International Earth Science Information Network of Columbia University, 2005), etc. This way of aggregation, according to the developers of Environmental Sustainability Index, is the most transparent way of combining the three-dimensional information into one measurement.

\section{Modeling Framework and Data}

In order to assess the systematic general equilibrium effects of trade liberalization on sustainability, we used a multi-country, multi-region CGE model, called GTAPST, which is a refinement of the GTAP model (Hertel, 1997), in the version modified by Truong (1999) and by Berrittella et al. (2005). The original GTAP model is a comparative static, multi-commodity, multi-region model with the 
assumptions of perfect competition and market equilibrium. This CGE model has been widely used for analyzing the impacts of economic growth (Johansen, 1960; Jorgenson, 1998), international trade (Devarajan et al., 1990; Markusen et al., 1995; Ianchovichian, 2004; Konan et al., 2006) and environmental policies (Mckibbin et al. 1996; Bosello and Zhang, 2005). Truong (1999) developed the GTAP-E model, which is suited for the analysis of energy markets and environmental issues (Burniaux et al., 2002), and climate change impacts (Bosello et al., 2005, Berrittella et al., 2006; McKibbin et al, 1998; Manne et al, 1996). The GTAP-E extends the conventional GTAP model by adding a module for energy-capital composite such as oil, gas, electricity and a module of $\mathrm{CO}_{2}$ emissions. Furthermore, Berrittella et al. $(2005,2007)$ introduced GTAP-W and modeled water resources as non-marketed goods in the GTAP-E model. Besides the variants such as public expenditure and environmental variables (e.g. $\mathrm{CO}_{2}$ ) from standard GTAP-E model, in the GTAP-ST we also include global water resources and further disaggregate GTAP-W model from 8 regions to 16 regions. These extensions of model structure give us more detailed information on the natural resources and environmental issues. In the GTAP-ST model trade liberalization scenarios are carefully designed and calculated for different regions and sectors. The structure of the model can be found in the Appendix (Figure A1 and Figure A2).

Figure A1. Nested tree structure for industrial production process

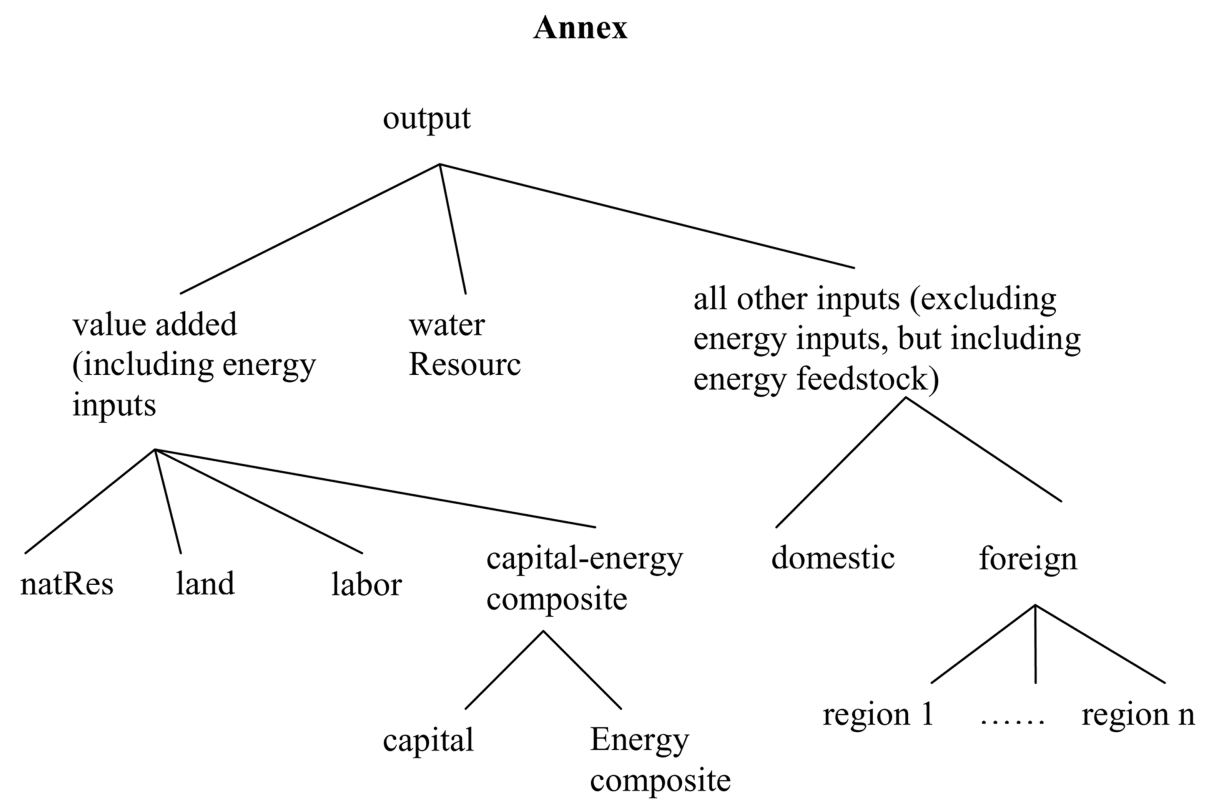


Figure A2. Nested tree structure for final demand

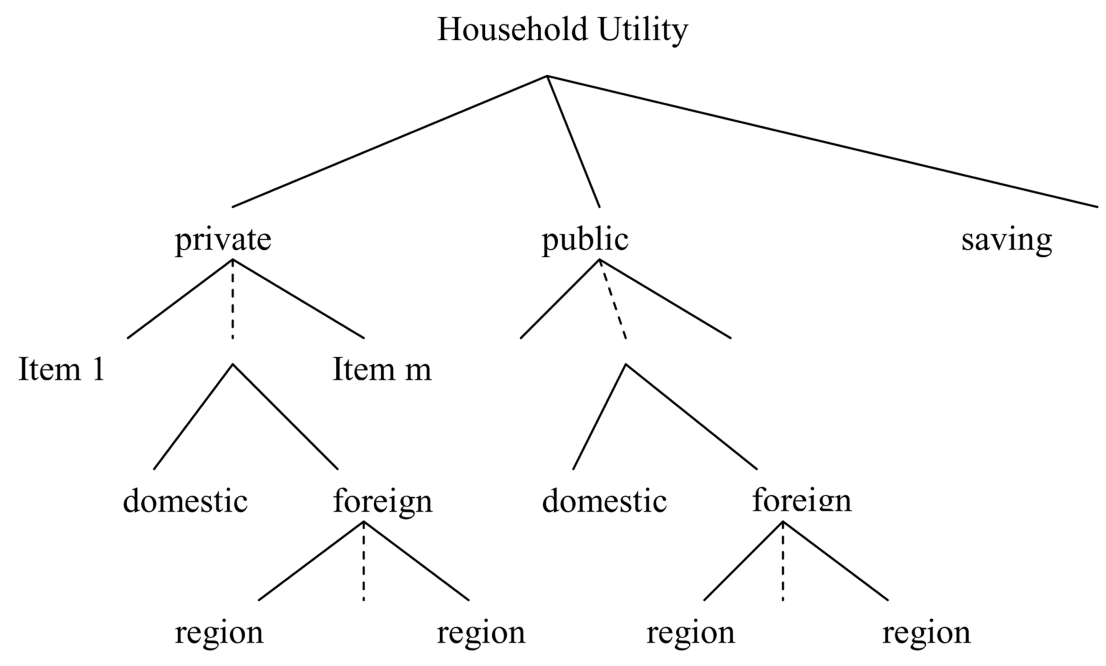

We employed the GTAP-ST model by aggregating the world economy from 87 into 16 regions, with each representing either a single country or a composite region of several countries (Table 1). For this, we used the GTAP database, version 5, which contains the 1997 world economy data. The aggregation of regions is primarily based on their importance in world production, consumption, and leading trading geopolitical group in Doha Round trade negotiation and economic development status. Table 1 also represents a clear distinction between the three major region groups studied in this paper, namely developed, developing and least developed regions. Each region's economy is further divided into 17 sectors or commodity groups with emphasis on agriculture products, energy products and related sectors (Table 1). According to its comparative advantages, each region produces its own unique variety of commodities using primary factors, such as labor, capital, land, and natural resources and intermediate inputs of domesticallyproduced and/or imported products. The production process is represented by a nested constant elasticity of substitution (CES) structure. Each primary factor is supplied to industries from its fixed regional endowment. Labor and capital are perfectly mobile domestically, but immobile internationally. Land and natural resources are industry-specific. Therefore, wages for each category of labor and the user price of capital are uniform across industries, but the rental prices of land and natural resources can vary from sector to sector.

Commodities produced in each region are either used to meet domestic demands (as intermediate inputs in production or final products in consumption) or exported 
Table 1. Region and sector aggregation

\begin{tabular}{llll}
\hline \multicolumn{1}{c}{ Region identifier } & \multicolumn{1}{c}{ Country/Region } & Sector identifier & Sector \\
\hline USA (developed country) & the United States & Rice & Rice \\
CAN (developed country) & Canada & Wheat & Wheat \\
WEU (developed region) & Western European countries & CerCrops & Cereals and Crops \\
JPK (developed country) & Japan & VegFruits & Vegetables and Fruits \\
ANZ (developed region) & Australia, New Zealand & Animals & Animals \\
EEU (developed region) & Eastern European countries & Forestry & Forestry \\
FSU (developed region) & Former Soviet Union & Fishing & Fishing \\
MDE (developing region) & Middle East & Coal & Coal \\
CAM (developing region) & Central America & Oil & Oil \\
SAM (developing region) & South America & Gas & Gas \\
SEA (developing region) & South-East Asia & Oil_Pcts & Oil Products \\
CHI (developing region) & China plus Hong Kong & Electricity & Electricity \\
ROW (developing region) & Rest of the world & Water & Water distribution services \\
SAS (least developing region) & South Asia & En_Int_Ind & Energy Intensive Industries \\
NAF (least developing region) & North Africa & Oth_Ind & Other Industries \\
SSA (least developing region) & Sub-Saharan Africa & Mserv & NMServ \\
& & & Market Services \\
& & Non-market Services &
\end{tabular}


to other regions. Both intermediate and final products from different regions are considered to be imperfectly substitutable with each other (Armington, 1969).

The final demand consists of investment, government consumption, and private consumption, each of which consumes composite commodities that are CES combinations of domestic and imported varieties. Government consumption is determined by the maximization of a Cobb-Douglas utility function. A constantdifference-elasticity (CDE) utility function is used for determining private consumption. Investments are financed by savings, and they are in equilibrium only at the global level, implying that capital can move across countries. The rate of returns from capital determines the capital investment and flows. The current account is not necessarily balanced for each country/region. Finally, global transportation costs are accounted by using the difference between the f.o.b. (free on board) and c.i.f. (cost, insurance, and freight) values.

\section{Design of model experiments}

The aims of the November 2001 declaration of the Fourth Ministerial Conference in Doha, Qatar, were to establish a fair and market-oriented trading system through a programme of fundamental reforms. The original Doha mandate was refined at Cancún in 2003, Geneva in 2004 and Hong Kong in 2005, but still the consensus for different issues of the negotiations was not achieved. In fact, on the one hand, the developing regions demand a reduction in the development of the high subsidies in agriculture products, so that products from developing countries can access the market in the developed countries. For example, the USA and Europe have high government subsidies to farmers, as such it will be difficult for agriculture products from developing regions to compete. On the other hand, developed regions argue that trade barriers in developing regions are still quite high leading to limited market access of products from developed into developing regions. How to get rid of this roadblock is still one of the key points that determine whether the Doha Round can be revived. Furthermore, other issue-linkages have to be taken into account in the evaluation of any trade policies, for example, their impacts on the environment. In fact, environment and trade policies should be mutually supportive. In particular, here, we face the question on how trade liberalization affects sustainability in the three dimensions (economic, environment and social) by proposing two scenarios, reported in Table 2, which have been defined on the basis of the Doha Round, and implemented by three instruments: import tariff, 
Table 2. Scenarios Design

\begin{tabular}{|c|c|}
\hline Scenario & Description \\
\hline Scenario A & $\begin{array}{l}\text { For the developed regions, there will be } 60 \% \text { reduction of tariff rates, } \\
\text { export subsidies, and output subsidies in non-services sectors (sector }\end{array}$ \\
\hline Partial Trade & $1-15)$. \\
\hline \multirow[t]{2}{*}{ Liberalization (PTL) } & $\begin{array}{l}\text { For developing countries, there will be } 40 \% \text { reduction of tariff rates, } \\
\text { export subsidies, and output subsidies in non-services sectors(sector } \\
1-15 \text { ) }\end{array}$ \\
\hline & $\begin{array}{l}\text { For least developing regions, zero reduction of tariff rates, export sub- } \\
\text { sidies, and output subsidies in all sectors }\end{array}$ \\
\hline Scenario A2010 & Scenario A (PTL) for the year 2010. \\
\hline Scenario A2030 & Scenario A (PTL) for the year 2030. \\
\hline Scenario B & $\begin{array}{l}\text { For the developed regions, there will be } 60 \% \text { reduction of tariff rates, } \\
\text { export subsidies, and output subsidies in non-services sectors(sector }\end{array}$ \\
\hline Deep Trade & $1-7) ; 40 \%$ reduction in manufacture and services sectors (sector $8-17$ ). \\
\hline \multirow[t]{2}{*}{ Liberalization (DTL) } & $\begin{array}{l}\text { For developing countries, there will be } 40 \% \text { reduction of tariff rates, } \\
\text { export subsidies, and output subsidies in non-services sectors (sector } \\
1-7) ; 20 \% \text { reduction of tariff rates, export subsidies, and output subsi- } \\
\text { dies in manufacture and service sectors (sector 8-17) }\end{array}$ \\
\hline & $\begin{array}{l}\text { For least developing regions, zero reduction of tariff rates, export sub- } \\
\text { sidies, and output subsidies in all sectors. }\end{array}$ \\
\hline Scenario B2010 & Scenario B (DTL) for the year 2010. \\
\hline Scenario B2030 & Scenario B (DTL) for the year 2030. \\
\hline
\end{tabular}

export subsidies and output subsidies. In the first scenario, called Partial Trade Liberalization (PTL), for each developed regions there are $60 \%$ reductions of the three instruments in the first fifteen sectors (non-service sector); while for developing countries, for each region there are $40 \%$ reductions of all three instruments in the first fifteen sectors. In the second scenario, called Deep Trade Liberalization (DTL), we impose different trade rates amongst agriculture sectors, manufacture sectors and services sectors. For developed regions, there are $60 \%$ reductions of tariff, export subsidies and output subsidies in agriculture sectors, and $40 \%$ reductions of these three policies in manufacture and services sectors. For developing regions, there are $40 \%$ reductions in agriculture sectors and $20 \%$ reductions in manufacture and services sectors.

Furthermore, because members of the Doha Ministerial Declaration aim to eliminate the tariffs by 2008-2010, we design the scenarios PTL and DTL for the year 2010 and 2030. For this, we derived a hypothetical data-set for the selected years, similar to Berrittella et al. (2006). This entails inserting calibration data in the model, forecasted values for some key economic variables (i.e. national 
endowments of labour, capital, land, etc.) in order to identify a hypothetical general equilibrium state in the future using the methodology described in Dixon and Rimmer (2002). In particular, the estimates of the regional labour and capital stocks have been obtained by running the G-Cubed model (McKibbin and Wilcoxen (1998). The estimates of land endowments and agricultural land productivity were obtained from the IMAGE model version 2.2 (IMAGE, 2001) by adopting the most conservative scenario regarding climate change (IPCC B1) and assuming minimal temperature variations. A rather specific methodology was adopted to obtain estimates for the natural resources stock variables. As explained in Hertel and Tsigas (2002), values for these variables in the original GTAP data set were not obtained from official statistics, but indirectly estimated, to make the model consistent with some industry supply elasticity values, obtained from the literature.

For this reason, we preferred to fix the price of the natural resources exogenously, making it variable over time in line with the GDP deflator, while allowing the model to endogenously compute stock levels.

Furthermore, we have calculated the impacts of trade liberalization on sustainability for 2010 and 2030 in order to underline the development of these impacts over time. For this, we developed hypothetical data-sets, and ran the PTL and DTL scenarios for the year 2030, following the methodology previously explained in this section.

The Swiss Formula ${ }^{1}$ is employed to calculate the import tariff, export subsidies and output subsidies in each sector and each country/region in different time frame. Our experiments are novel because we focus on trade liberalization in agriculture and manufacture sectors, while taking into account the trade negotiations of the services sectors, especially for developed regions and some developing regions at the global level. Further, we measure trade liberalization impacts on sustainability in three-dimensions: economic, environment and social simultaneously.

\section{Simulation Results}

Globalization and increasing international trade have direct impacts on society, livelihoods and the environment (Gallagher and Werksman, 2002). This connects

\footnotetext{
${ }^{1} t_{1}=\frac{(a \text { or } b) \times t_{0}}{(a \text { or } b)+t_{0}}$, where $\underline{t}_{1}=$ Final bound tariff; $t_{0}=$ Base rate; $a$ and $b$ are the coefficient for developed regions and developing regions, respectively.
} 
Table 3. Decomposition of welfare change in North Africa

\begin{tabular}{lc}
\hline \multicolumn{1}{c}{ Description } & Change in mln US \$ \\
\hline Change in the price of capital goods & -82.531 \\
Change in the use of domestic intermediate inputs in all industries & 0.175 \\
Change in the use of imported intermediate inputs in all industries & -15.309 \\
Change in the imports from all regions & -261.201 \\
Change in the output & -0.013 \\
Change in the consumption of domestic goods & -8.988 \\
Change in the consumption of imported goods & -10.114 \\
Change in the exports of all goods & 107.334 \\
Change in terms of trade & -173.004 \\
Total EV & -443.651 \\
\hline
\end{tabular}

the concept of trade with sustainability, which integrates closely interlinked economic, social and environmental issues. The results of our study emphasize these close linkages between the three dimensions by analyzing the impacts of PTL and DTL scenarios on sustainability performance. We also briefly discuss the development of the impacts on sustainability over time, from 2010 to 2030.

\section{Economic sustainability}

Tables 4 and 6 report the impacts of trade liberalization on economic sustainability performance. In order to understand how trade liberalization affects welfare, we additionally reported the component of the Hicksian equivalent variation $\left(\mathrm{EV}^{2}\right)$ in terms of trade effect in Figure 1, which contributes to the main proportion of welfare changes for countries or regions. Amongst the developed countries, Western European countries (WEU) substantially gain from trade liberalization, due to an increase in imports at lower prices. The increased welfare in the USA is mainly due to the increase in the imports of agricultural and energy products. Japan (JPK) is worst off, because it increases the exports of energy intensive industries and services, both market and non-market.

Amongst the developing countries, Middle East (MDE) gains more than others, because it becomes a net importer (Figure 1), mainly, due to the increase in the imports of agricultural goods. On the other hand, trade liberalization negatively impacts China's (CHI) welfare due to the increase in the exports of rice and energy

\footnotetext{
${ }^{2}$ The welfare of a country (region) is represented by EV (equivalent variation), which is computed as: $\mathrm{EV}(\mathrm{REGION})=\mathrm{U}(\mathrm{REGION}) * \operatorname{INC}(\mathrm{REGION}) / 100$, where $\mathrm{U}(\mathrm{REGION})$ is the percent change in per capita welfare in each country (region) and INC(REGION) represents income in each country (region).
} 
Table 4. Impacts of trade liberalization on sustainable development indicators (in $\%$ change, scenario PTL, 2010)

\begin{tabular}{lccccc}
\hline \multirow{2}{*}{ Region } & \multicolumn{2}{c}{ Economic indicators } & Social indicator & \multicolumn{2}{c}{ Environmental indicators } \\
\cline { 2 - 6 } & $\begin{array}{c}\text { GDP } \\
\text { per capita }\end{array}$ & $\begin{array}{c}\text { Investment as } \\
\text { \% of GDP }\end{array}$ & $\begin{array}{c}\text { Public expenditure } \\
\text { per capita }\end{array}$ & $\begin{array}{c}\mathrm{CO}_{2} \text { emissions } \\
\text { per capita }\end{array}$ & $\begin{array}{c}\text { Water resources } \\
\text { use per capita }\end{array}$ \\
\hline USA & 0.005 & -2.483 & 0.058 & -0.048 & 1.371 \\
CAN & -0.010 & 0.930 & -0.643 & 3.974 & -0.313 \\
WEU & 0.045 & 2.417 & -0.684 & 2.255 & -0.292 \\
JPK & 0.039 & -1.285 & -0.400 & -0.233 & -3.289 \\
ANZ & 0.017 & -1.857 & -0.133 & -1.642 & 12.335 \\
EEU & 0.378 & 8.086 & -1.677 & 1.998 & -2.424 \\
FSU & 0.117 & 2.548 & -0.454 & 1.559 & -0.094 \\
MDE & 0.329 & 4.941 & -0.034 & 3.191 & -0.339 \\
CAM & 0.128 & 1.547 & -0.785 & 3.657 & 2.431 \\
SAM & 0.144 & -0.652 & -0.536 & -0.473 & 0.190 \\
SAS & 0.095 & -1.891 & 0.196 & 0.077 & 0.400 \\
SEA & 0.094 & 1.787 & -1.357 & 1.463 & 0.271 \\
CHI & 0.130 & -0.218 & -0.825 & 0.800 & -0.248 \\
NAF & -0.054 & -2.512 & -0.144 & -0.671 & 1.066 \\
SSA & -0.037 & -2.525 & 0.068 & -0.488 & 0.579 \\
ROW & 0.177 & 0.057 & -0.973 & 1.109 & 0.134 \\
\hline
\end{tabular}

Table 5. Impacts of trade liberalization on Equivalent Variation (EV) (change in mln US \$, 2010)

\begin{tabular}{lcc}
\hline Region & $\begin{array}{c}\text { EV in PTL Scenario } \\
\text { (change in mln US \$) }\end{array}$ & $\begin{array}{c}\text { EV in DTL Scenario } \\
\text { (change in mln US \$) }\end{array}$ \\
\hline USA & 7354 & -2320 \\
CAN & -3184 & -1498 \\
WEU & 27236 & 28505 \\
JPK & -11806 & -1121 \\
ANZ & -414 & -526 \\
EEU & -2876 & -1902 \\
FSU & 1327 & 1123 \\
MDE & 7574 & 4074 \\
CAM & -625 & -150 \\
SAM & 1096 & 758 \\
SAS & 1801 & 595 \\
SEA & 571 & -25 \\
CHI & -4186 & -2784 \\
NAF & -444 & -766 \\
SSA & 147 & -192 \\
ROW & -789 & -585 \\
\hline
\end{tabular}


Table 6. Impacts of trade liberalization on sustainability indicators (in \% change, scenario DTL, 2010)

\begin{tabular}{lccccc}
\hline \multirow{2}{*}{ Region } & \multicolumn{2}{c}{ Economic indicators } & Social indicator & \multicolumn{2}{c}{ Environmental indicators } \\
\cline { 2 - 6 } & $\begin{array}{c}\text { GDP } \\
\text { per capita }\end{array}$ & $\begin{array}{c}\text { Investment as } \\
\text { \% of GDP }\end{array}$ & $\begin{array}{c}\text { Public expenditure } \\
\text { per capita }\end{array}$ & $\begin{array}{c}\mathrm{CO}_{2} \text { emissions } \\
\text { per capita }\end{array}$ & $\begin{array}{c}\text { Water resources } \\
\text { use per capita }\end{array}$ \\
\hline USA & -3.711 & -0.021 & -0.019 & 1.628 & -3.711 \\
CAN & 0.249 & -0.438 & 2.765 & -0.281 & 0.249 \\
WEU & 2.863 & -1.236 & 1.672 & -0.990 & 2.863 \\
JPK & 0.948 & -2.016 & -0.032 & -3.906 & 0.948 \\
ANZ & -3.222 & -0.094 & -0.927 & 12.361 & -3.222 \\
EEU & 4.745 & -1.198 & 1.447 & -2.058 & 4.745 \\
FSU & 2.408 & -0.645 & 1.025 & -0.340 & 2.408 \\
MDE & 2.075 & -0.298 & 1.638 & 0.508 & 2.075 \\
CAM & 0.868 & -0.892 & 1.806 & 1.778 & 0.868 \\
SAM & 0.414 & -1.037 & -0.123 & -0.462 & 0.414 \\
SAS & -2.693 & 0.116 & 0.041 & 0.516 & -2.693 \\
SEA & 0.608 & -1.053 & 0.755 & -0.136 & 0.608 \\
CHI & -0.126 & -0.711 & 0.453 & -0.438 & -0.126 \\
NAF & -3.170 & -0.271 & -0.568 & 1.228 & -3.170 \\
SSA & -3.276 & 0.018 & -0.214 & 0.877 & -3.276 \\
ROW & -1.331 & -0.587 & 0.544 & 0.175 & -1.331 \\
\hline
\end{tabular}

Figure 1. Impacts of trade liberalization on welfare and trade change (Scenario PTL, 2010)

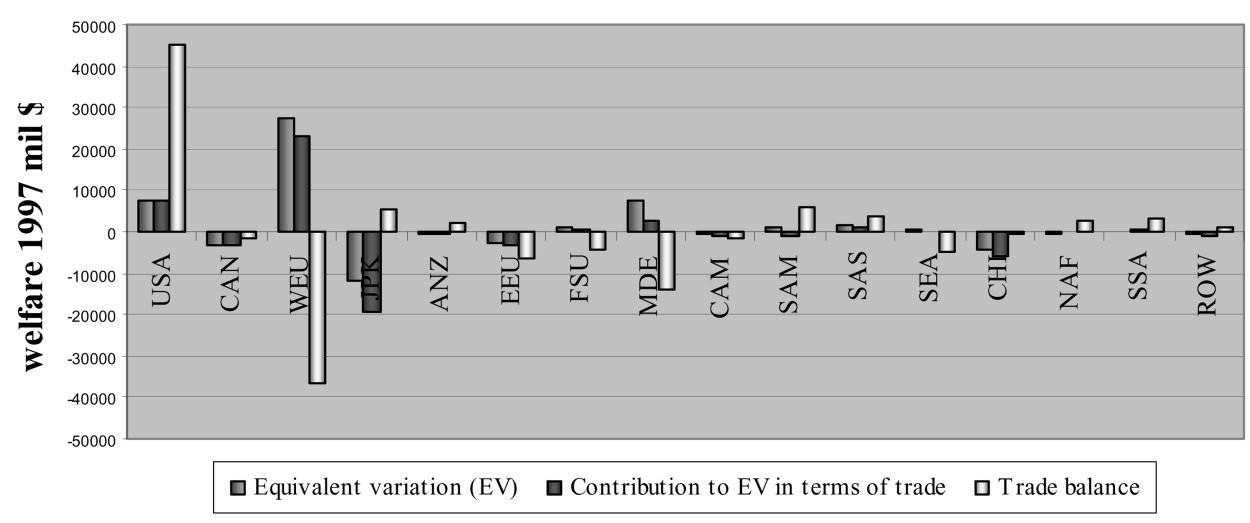

products. The other developing countries as well as the least developed regions or countries (LDCs) are slightly affected by trade liberalization. Results from our scenario designs, indicate that the net welfare of a country or region depends on the net effects of term of trade, resource allocation, import/export price, output and other effects shown in Table 3. 
The Doha agreements of trade liberalization are supposed to be an incentive mainly for Africa, but Figure 1 shows that North Africa (NAF) suffers loses from the trade liberalization instead of gaining from the trade. The decomposition of contributions to the welfare change in terms of equivalent variation (EV), reported in Tables 3 and 5, reveals that the EV change in terms of trade in North Africa (NAF) decreases, price of capital goods drops, and imports from all other regions fall. These negative effects outweigh the positive effect of a rise in export, therefore, the total net welfare is negative.

Globally, developed and developing regions gain from trade liberalization, but the results suggest that a problem of welfare redistribution would arise within each group. For example, there should be welfare transfer to China and rest of world (ROW) from the other developing countries, to incentive China and rest of the world to join the trade agreement. If DTL scenario takes place, Japan (JPK) and USA are substantially affected, but in different ways (Table 6). In fact, in this scenario Japan gains with respect to the PTL scenario due to an increase in imports of energy-intensive products (Table 4); however, USA becomes worse off with respect to the PTL scenario, because it increases the exports of those products. World welfare increases from further trade liberalization, but the main gainers are only the developed countries. In fact, results of economic indicators suggest that developing countries would prefer gradual trade liberalization, as the PTL scenario.

The other economic indicators exhibit similar trends compared to the results in terms of welfare. Eastern European countries and Japan gain more than Western European countries and USA in terms of GDP per capita rather than in terms of welfare. This finding may be also due to the fact that they have lower population levels than the other two. Amongst the developing countries, Middle East has the highest benefits in terms of GDP growth. The overall trend of the investment as percentage of GDP does not follow a linear intuition. The higher the investment, the higher is the GDP. Western European countries and Eastern European countries sustain the highest investment expenditure amongst the developed countries, and Middle East amongst the developing countries. Globally, if the PTL scenario takes place, Western European countries and Japan gain more than in the DTL scenario in terms of economic indicators (Tables 4 and 6) and so does the developing countries (Figures 2 and 3). Economically least developing economies gain less in Partial liberalization than Deep liberalization because they gain more from lower trade barrier. However, in terms of economic indicators, under both PTL and DTL scenarios, least developed countries would be worse off compared to more 
Figure 2. Impacts of Trade Liberalization on Sustainability (Scenario PTL, 2010)

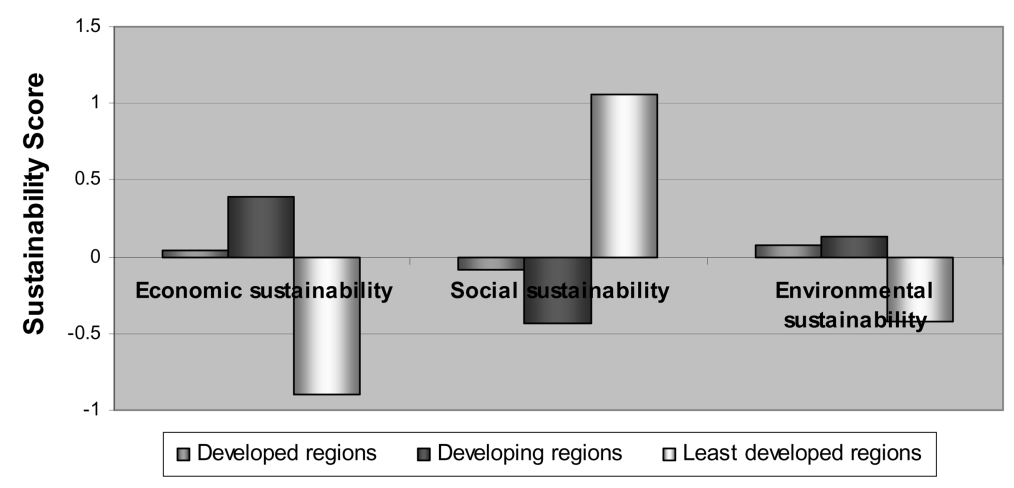

Figure 3. Impacts of Trade Liberalization on Sustainability (Scenario DTL, 2010)

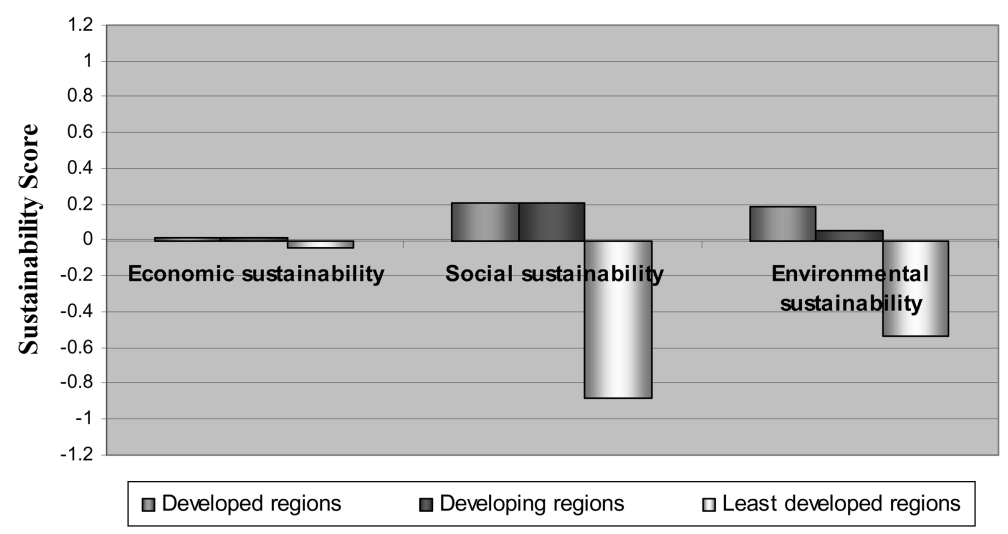

developed regions, suggesting that special treatments and time frame may need to be considered in the future negotiation talks.

\section{Social sustainability}

The impacts of trade policy on social sustainability are negative for almost all the countries in the PTL scenario (Tables 4 and 6) and only the least developed countries have overall positive gains in PTL scenario (Figure 2). The high social sustainability performance observed for least developed countries (LDC) in the PTL scenario is mainly determined by the positive social sustainability impacts on South Asia and Sub-Saharan Africa regions. The high level of social sustainability performance in LDC in the PTL scenario may result from bias due to the small number of regions used in the Equally Weighted Average (EWA) method (we have only three LDC regions). Another reason for causing such a high positive change 
in the PTL for LDC may be due to data collection problem in GTAP data base.

The above reported impacts on social sustainability of the regions relate to the fact that trade liberalization incentives the production of mainly non-services sectors; whereas, social indicators include the public expenditure per capita, which aggregates the per-capita expenditure on defense, health, education and public administration. Figure 3 shows that globally in the DTL scenario developed and developing regions demonstrate positive impacts on social sustainability, while DTL impacts on social sustainability of least developed regions are negative. This suggests that in terms of social dimension gradual trade liberalization (PTL) for least developed regions is a more acceptable scenario.

\section{Environmental sustainability}

In terms of environmental indicators, sustainability increases if the $\mathrm{CO}_{2}$ emissions per capita decreases and/or the water resources use per capita increases. The results depend on a combination of the population level and trade of agricultural and energy products and services. In the PTL scenario, the USA gains, because it is a net importer of agricultural and energy products. In fact, by reducing the production of agricultural goods in USA, the water resources use decreases and, hence, it increases the water availability per capita; on the contrary, reduction in the production of energy goods and services reduces the $\mathrm{CO}_{2}$ emissions level and, hence, the $\mathrm{CO}_{2}$ emissions per capita. In the DTL scenario the USA is worst off in terms of $\mathrm{CO}_{2}$ emissions, because it increases the exports of energy products and services. Amongst the developed countries also Australia and New Zealand (ANZ) substantially gain in terms of both environmental indicators, and this is mainly due to the low population levels in this region. However, globally, the developed countries are positively affected in both scenarios, but they are better off in the DTL (Figure 2, Figure 3). This supports the earlier observation of our study that developed countries are the gainers in DTL scenario. On the contrary, in terms of environmental performance, the developing countries are gainers in the PTL scenario. The least developed countries are negatively affected in both scenarios; however, in PTL scenario negative impacts on environmental sustainability of LDC are lower.

\section{Sustainability triangles}

In order to be sustainable trade liberalization must be economically profitable, environmentally and socially acceptable. These three considerations can be 
described as the "sustainability triangle". The idea to reflect sustainability components in one figure (e.g. triangle) has been used in a number of studies on sustainable development (e.g. Munasinghe, 2004; Yale Center of Environmental Law and Policy and Center for International Earth Science Information Network of Columbia University, 2005). Thus, in our study we applied a similar "sustainability triangle" approach, which allowed us to graphically illustrate the sustainability performance of the regions along the three sustainability dimensions.

Figures 4 and 5 illustrate sustainability levels of developed, developing and least developed regions or countries (LDCs), and simultaneously reflects the economic, social and environmental performances of these three groups. The lowest sustainability levels are those located lying closest to the intersection of the three axes. Thus, the further are the levels from the intersection point, the higher is the sustainability performance. There is some divergence amongst the impacts of trade liberalization on sustainability indicators. As it can be observed in the PTL scenario

Figure 4. Impacts of Trade Liberalization on the Three Sustainability Dimensions (Scenaric PTL, 2010)

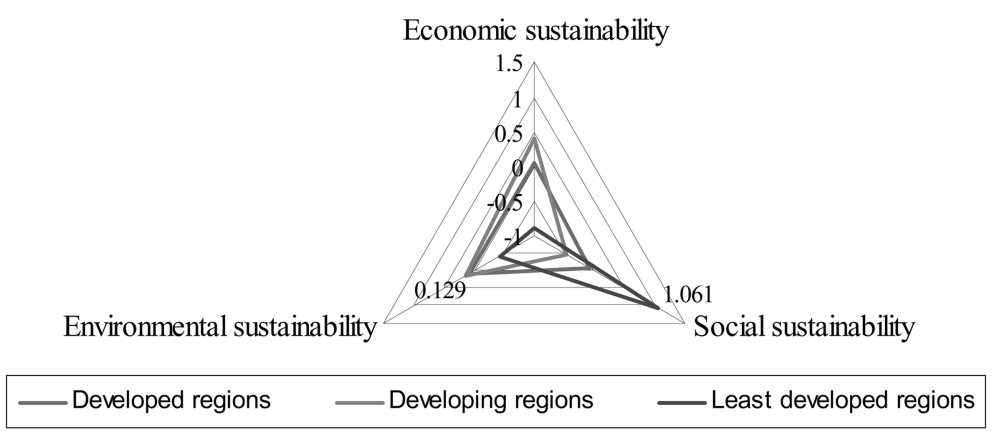

Figure 5. Impacts of Trade Liberalization on the Three Sustainability Dimensions (Scenaric DTL, 2010)

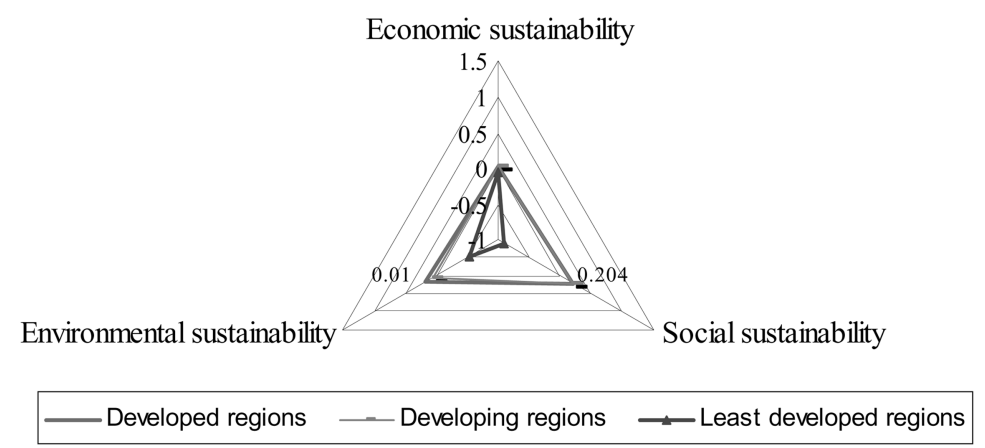


(Figure 4) in least developed regions economic sustainability is very low, environmental performance is relatively the same as in DTL, but impacts on social sustainability are even higher than in developed and developing regions. As it can see from the triangle figures, in 2010 overall sustainability levels are clearly more equally balanced along the three sustainability dimensions in DTL for developing regions (Figure 5) compared to the PTL scenario, while developed countries seem to have similarly balanced sustainability levels in both scenarios (Figures 4 and 5). Least developed countries find the PTL policy scenario more acceptable in terms of social sustainability and DTL in terms of economic sustainability. Figure 6 presents the summarized preference of developed and developing regions for DTL scenario and least developing regions for PTL scenario based on the sustainability scores in 2010.

The sustainability scores under PTL and DTL scenarios in 2030 reveal that

Figure 6. Impacts of Trade Liberalization on Sustainability Score in 2010

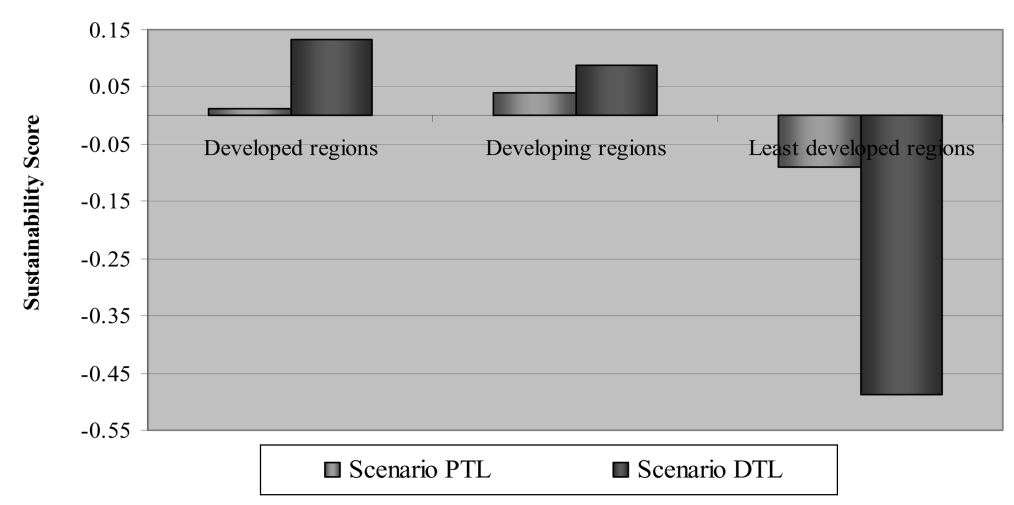

Figure 7. Impacts of Trade Liberalization on Sustainability Score in 2030

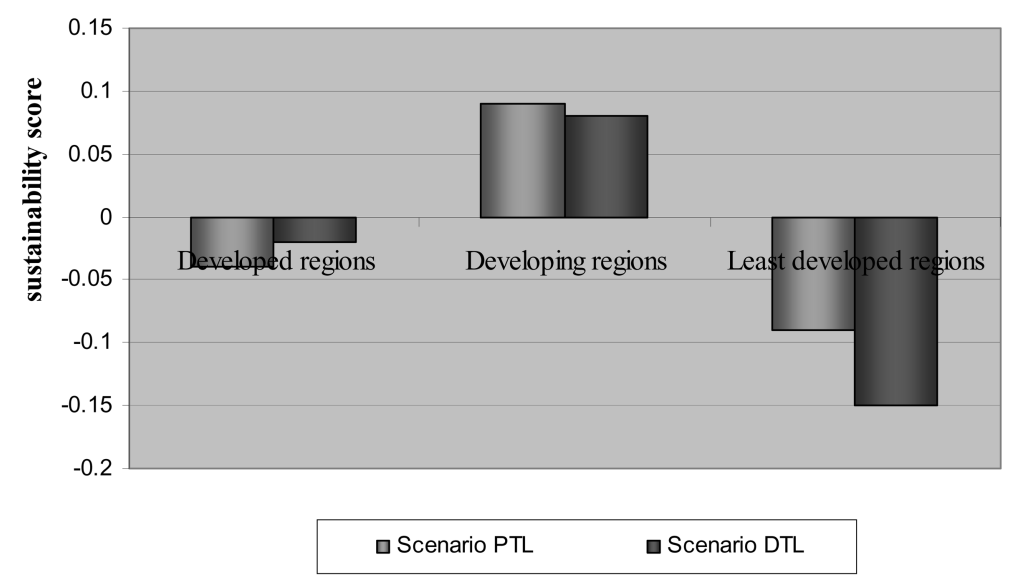


developing and least developed regions in the long term may prefer gradual trade liberalization. As it can be seen from Figure 7, the PTL scenario in 2030 compared to 2010 results in higher sustainability performance for these regions. This suggests that gradual trade liberalization is the more preferred policy in long term rather than in short for developing and least developed regions. Among all the regions both in 2010 and 2030 and in both trade policy scenarios least developing regions have the lowest sustainability scores.

\section{Conclusions}

Inspired by the growing international debate in the field of trade liberalization and sustainable development, this study discusses how two trade liberalization policy scenarios can affect sustainable development on the global level. Derived from the negotiations of Doha Ministerial Declaration (2001), which were further refined in Cancun, Genève and Hong Kong, the partial trade liberalization and deep trade liberalization scenarios were designed to analyze these impacts.

The two main results of the macroeconomic analysis can be concluded from this study. Firstly, developed and developing regions gain from trade liberalization, but welfare is unevenly redistributed among each group. Secondly, the impacts are more substantial in industrialized countries, but are often most harsh in developing economies (Gallagher and Werksman, 2002) as it can be observed in the case of least developed regions. For least developed regions gradual trade liberalization, such as the PTL scenario, is more acceptable than deep trade liberalization.

According to the above findings, economic indicators, such as GDP per capita and investment reveal that PTL is more beneficial for developed and developing countries in comparison to DTL scenario. As trade liberalization positively affects economic growth, it may have different impacts on social and environmental dimensions. While for these regions in terms of economic development PTL scenario is more preferred, social impacts are mainly negative in PTL, but positive in DTL. Impacts of rapid economic growth reflect on lower environmental performance. However, in spite of divergence observed in the results among the countries in terms of environmental and social performance, globally DTL is more acceptable for developed and developing countries, while PTL -for least developed regions. Another interesting finding from all these scenarios is that while in PTL both developed and developing regions have high achievements in economics and environmental sustainability dimension, social sustainability is very low. This 
indicates that the gap between the poor and rich regions is increasing rather than decreasing. Furthermore, least developed regions have only negligible performance of environmental sustainability and social sustainability in DTL. In other words, in longer term DTL may also result in worse off in economic dimension in the least developed regions. In conclusion, the policy implications from our study suggest that trade liberalization impacts are unevenly distributed between different regions or within each region in terms of the aspects of social, economic and environmental dimensions. Globally developed and developing countries are better off with DTL trade liberalization policy, while gradual trade liberalization (i.e. PTL) is more preferred by the least developed regions. However, developing regions would substantially gain in terms of sustainability in the long period under PTL rather than in the short period. In long term PTL is also a more acceptable scenario than DTL for least developing regions. This is perhaps due to the fact that developing regions are not strong enough economically to accept deep trade liberalization in the long run. Gradual "soft landing" in trade liberalization policy maybe better than "hard landing" in the short run and long run for developing and least developed regions or countries. Nevertheless, it has to be recognized that trade liberalization plays a significant role in sustainable development and in poverty eradication on the global level and, thus, the issue deserves further scientific attention. There is a continuing need to support efforts by developing countries to integrate themselves into and derive benefits from the multilateral trading system.

\section{Acknowledgements}

We would like to thank Katrin Rehdanz, and Richard Tol for providing useful comments and water dataset; Francesco Bosello, Marco Lazzarin, Andrea Galvan and Roberto Roson for developing the benchmark dataset; Jean - Francois Vinuesa for his help with statistical analysis of sustainability indicators, Denise Eby Konan, Elisa Lanzi and Enrica De Cian for helpful comments. The Ecological and Environmental Economics (EEE) programme, c/o International Centre for Theoretical Physics (ICTP/UNESCO/IAEA, Trieste, Italy) provided welcome financial support. Finally, but not less important, we are grateful to Carlo Carraro for his encouragement in our scientific research. All errors and opinions remain ours.

\section{Appendix}

Hicksian equivalent variation 
Consider a price change from to $p^{\prime}$. The number

$E V\left(p, p^{\prime}, w\right)=e\left(p, v\left(p^{\prime}, w\right)\right)-w$ is called the equivalent variation.

Remark 1: We have $E V\left(p, p^{\prime}, w\right)>0$ if and only if the consumer is better off in $\left(p^{\prime}, w\right)$ than in $(p, w)$

Remark 2: We have $E V\left(p, p^{\prime \prime}, w\right)>E V\left(p, p^{\prime}, w\right)$ if and only if the consumer is better off in $\left(p^{\prime \prime}, w\right)$ than in $\left(p^{\prime}, w\right)$

Remark 3: Equivalent Variation can be expressed as areas under Hicksian demand curves.

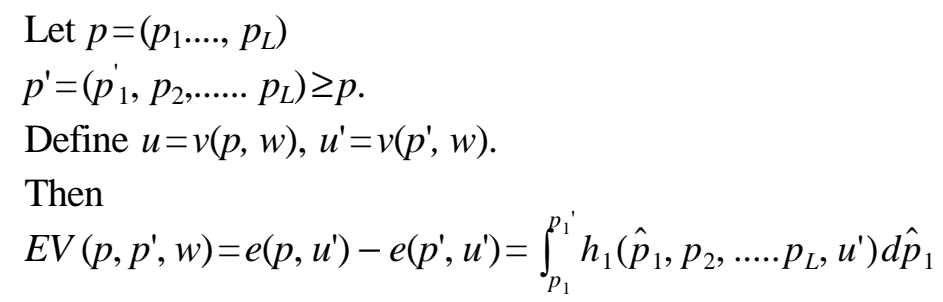

Received 4 January 2007, Accepted 11 June 2007

\section{References}

Armington, A (1969) Theory of demand for products distinguished by place of production, IMF Staff Papers, 16, 159-178.

Arrow, K., P. Dasgupta, L. Goulder, G. Daily, P. Ehrlich, G. Heal, S. Levin, K.G. Maler, S. Schneider, D. Starrett, and B. Walker (2004) Are We Consuming Too Much?, Journal of Economics Perspectives, 18(3), 147-172.

Arrow, K., P. Dasgutpa, Mäler, K.-G. (2003) Evaluating Projects and Assessing Sustainable Development in Imperfect Economies, Environmental and Resource Economics, 26: 647-685.

Asheim, G. (2003) Green National Accounts for Welfare and Sustainability: A Taxonomy of Assumptions and Results, Scottish Journal of Political Economy, 50(2), 113-30.

Asheim, G. (1994) Net national product as an indicator of sustainability, Scand. J. Econ., 96, 257-265.

Berrittella, M., A.Y. Hoekstra, K. Rehdanz, R. Roson and R.S.J. Tol (2005) The Economic Impact of Restricted Water Supply: A Computable General Equilibrium Analysis, FNU93, Hamburg University and Centre for Marine and Atmospheric Science, Hamburg

Berrittella, M., A.Bigano, R. Roson and R.S.J. Tol (2006) A general equilibrium a nalysis of climate change impacts on tourism, Tourism Management, 27(5), 913-924. Berrittella, M, A.Y. Hoekstra, K. Rehdanz, R.Roson, R.S.J. Tol (2007), The economic impact of restricted water supply: A computable general equilibrium analysis, Water 
Reserch, 41, 1799-1813.

Bosello, F., R. Roson and R. Tol (2005) Economy - Wide Estimates of the Implications of Climate Change: Human Health, FEEM working paper. Fondazione ENI Enrico Mattei, Milan, Italy.

Bosello, F. and J. Zhang (2005) Assessing climate change impacts: agriculture, FEEM Working paper 94.05, Fondazione Eni Enrico Mattei, Venice, Italy. Burniaux, J. M.and T.P. Truong (2002) GTAP-E: An Energy-Environmental Version of the GTAP Model, GTAP Technical Paper. No.16. Dasgupta, P. and G.M. Heal (1979) Economic Theory and Exhaustible Resources. Cambridge: Cambridge University Press.

Devarajan, S., J.D. Lewis and S. Robinson (1990) Policy lessons from trade focused, twosector models, Journal of Policy Modeling 12, 625-657.

Dixon, P.B. and M.T. Rimmer (2002), Dynamic General Equilibrium Modelling for Forecasting and Policy: A Practical Guide and Documentation of MONASH, Contributions to Economic Analysis, North Holland Publishing Company, Amsterdam.

Francois, J.F., H.V. Meijl, and F.V. Tongeren (2005) Gauging the WTO negotiation's potential gains Doha Round, Economic Policy 349-391. Gallagher, K.P. and J. Werksman (2002), International Trade and Sustainable Development. Earthscan Publications Ltd. Heal, G.M. (1998), Valuing the Future: Economic Theory and Sustainability. New York: Columbia University Press. Hertel, T.W. and M. Tsigas (2002) GTAP Data Base Documentation. Chapter 18.c Primary Factors Shares (www.gtap.org) Hertel, T.W.(1997) Global trade analysis modeling and applications. Cambridge, UK: Cambridge University Press.

Hertel, T.W., Ivanic, M., Preckel, P. and Cranfield J. (2004) The Earnings Effects of Multilateral Trade Liberlization: Implications for Poverty in Developing Countries. GTAP Working Paper No. 16, 2004.

Hertel, T.W., Ivanic, M., Preckel, P. and Cranfield J. (2003) Trade Liberalisaton and the Strucuture of Poverty in Developing Countries. GTAP Working Ppaper No. 25.

Ianchovichian, E. (2004) Trade Policy Analysis in the Presence of Duty Drawbacks, Journal of Policy Modeling 26, 353-371

IMAGE, (2001), The IMAGE 2.2 implementation of the SRES scenarios. RIVM CDROM Publication 481508018, Bilthoven, The Netherlands.

Johansen, L. (1960) A Multi-Sectoral Study of Economic Growth. North-Holland Publishing Company. Amsterdam ( $2^{\text {nd }}$ Edition, 1974).

Jorgenson, D. (1998) Growth volume 2: energy, the environment, and economic growth. Cambridge, MA: The MIT Press.

Konan, D. and K.E. Maskus (2006) Quantifying the Impact of Services Liberalization in Tunisia, Journal of Development Economics, 81(1), 142-162.

Lofgren, H., El-Said M., and Robinson S. (1999) Trade liberalization and Complementary Domestic Policies: A Rural-Urban General Equilibrium Analysis of Morocco, Discussion Paper 41, International Food Policy Research Institute (IFPRI), Washington DC.

Manne, A.S., R. Mendelsohn and R.G. Richels (1996) MERGE: A Model for Evaluating Regional and Global Effects of GHG Reduction Policies, Energy Policy, 23(1), 17-34. 
Markusen, J. R., T. F. Rutherford, and L. Hunter (1995) Trade liberalization in a multinationaldominated industry, Journal of International Economics, 38, 95-118.

McKibbin, W.J. and P.J. Wilcoxen (1998) The theoretical and empirical structure of the Gcubed model, Economic Modelling, 16(1), 123-48.

Moosa, M.V. (2002) Linking Doha, Monterrey and Johannesburg: A Global Deal to Eradicate Poverty and Inequality and Promote Sustainable Development. UNDP Seminar of Financing of Global Public Goods.

Munasinghe, M. (2004) Environmental Macroeconomics - Basic Principles. Munasinghe Institute for Development (MIND), Colombo, Sri Lanka.

Nardo, M., Saisana, M., Saltelli, A., Tarantola, S., Hoffman, A. and Giovanni, E. (2005) Handbook on Constructing Indicators: Methodology and User Guide. OECD Statistics Working Paper STD/DOC(2005)3. Paris.

Nardo, M., Saisana, M., Saltelli, A. and Tarantola, S. (2005) Tools for Composite Indicators Building. Joint Research Centre (JRC), Ispra, Italy.

Pezzey, J. (1989) Definitions of Sustainability, Working Paper No. 9, Environment \& Behavior Program, Institute of Behavioral Sciences, University of Colorado, Boulder, $\mathrm{CO}$, August.

Pezzey, J. (1992) Sustainable Development Concepts: An Economic Analysis. World Bank Environment Paper No. 2, World Bank, Washington, D.C.

Solow, R. M. (1992) An Almost Practical Step toward Sustainability. Resources for the Future $40^{\text {th }}$ Anniversary Lecture, Washington, D.C.: Resources for the Future.

Suppan, S. (2005) Policy coherence and agricultural trade liberalization: Lessons for the Doha Round. In: Sailing Close to the Wind: Navigating the Hong Kong WTO Ministerial. Minneapolis, Institute for Agriculture and Trade Policy: 45-58.

Thrulow J. and Seventer D.E. (2002) A Standard Computable General Equilibrium Model for South Africa, Discussion Paper No 100, Trade and Macroeconomics Division, International Food Policy Research Institute. Washington DC.

Truong, T.P. (1999) GTAP-E. Incorporating Energy Substitution into GTAP-Model, Technical Paper 16. Center for Global Trade Analysis, Prudue University, Purdue.

United Nations Development Programme (2001). Making new technologies work for human development. Human Development Report. New York: United Nations Development Programme.

Viner, J. (1950) The Customs Union Issue. New York: Carnegie Foundation for International Peace.

World Commission on Environment and Development (WCED), 1987. Our Common Future, Oxford University Press.

World Trade Organization (WTO), 2001. Doha WTO Ministerial 2001: Ministerial declaration.

Yale Center for Environmental Law and Policy, Yale University and Center for International Earth Science Information Network, Columbia University (2005). 2005 Environmental Sustainability Index: Benchmarking National Environmental Stewardship. Available from: http://www.yale.edu/esi/ 